УдК 343.14

\title{
A. A. Коваль \\ ТЕОРЕТИЧНІ ТА ПРАКТИЧНІ ПРОБЛЕМИ ПРАВОВОГО РЕГУЛЮВАННЯ НЕГЛАСНИХ СЛІДЧИХ (РОЗШУКОВИХ) ДІЙ
}

Постановка проблеми. Судово-правова реформа, орієнтована на європейські стандарти, сприяла прийняттю нового Кримінального процесуального кодексу, який суттєво змінив концепцію кримінального судочинства. 3'явилися нові, незвичні для національної правової системи інститути. Серед найбільш радикальних новел - запровадження негласних слідчих (розшукових) дій (далі - НСРД).

Аналіз окремих кримінальних процесуальних норм, що регулюють проведення НСРД, дозволяє стверджувати, що правова регламентація та процесуальна форма проведення НСРД не позбавлена певних проблемних питань, які стосуються недоліків юридичної техніки, практичних аспектів проведення НСРД, порушення прав людини при їх провадженні.

Аналіз останніх досліджень і публікацій. Варто зазначити, що загальні проблеми правової регламентації слідчих дій вивчали у своїх працях Ю.П. Аленін, О.Я. Баєв, О.В. Капліна, В.О. Коновалова, М.І. Порубов, В.М. Стратонов, С.А. Шейфер, В.Ю. Шепітько, М.Є. Шумило та ін. Окремі питання провадження НСРД досліджували В.Д. Берназ, О.М. Дроздов, В.А. Колесник, Є.Д. Лук'янчиков, Д.П. Письменний, М.А. Погорецький, Д.Б. Сергєєва, О.Ю. Татаров, В.В. Тіщенко, В.М. Тертишник. Проте новизна досліджуваного інституту, складність провадження, суттєві обмеження прав людини під час проведення вимагають більш глибокого дослідження процесуальної форми НСРД, прогалин та неточностей у правовому регулюванні, розробки відповідних пропозицій для їх усунення.

Мета статті - на основі аналізу кримінального процесуального законодавства, судово-слідчої та адвокатської практики визначити окремі актуальні проблеми правового регулювання та провадження негласних слідчих (розшукових) дій в аспекті забезпечення конституційних прав людини.

Виклад основного матеріалу дослідження. Відповідно до конституційного принципу верховенства права, правозастосовної та інтерпретаційної практики Європейського суду прав людини, реформування сфери кримінального судочинства має бути спрямоване на реальний захист прав 
та свобод особи, їх утвердження і забезпечення. Норми КПК слід тлумачити та «звіряти із системою координат» Конвенції про захист прав людини й основоположних свобод та практики ЄСПЛ [1]. Ось чому основним завданням правової держави, а також кримінальної процесуальної політики має стати ефективне забезпечення захисту прав, свобод та законних інтересів людини, запровадження дієвої системи їх гарантій, обгрунтованості і доцільності обмеження, зокрема під час проведення НСРД.

У зв'язку із зазначеним нами було проведено аналіз кримінального процесуального законодавства, досліджено судову практику, а також проведено опитування суддів, прокурорів, слідчих, співробітників оперативних підрозділів та адвокатів, що дозволило нам зробити такий висновок. Правова регламентація та процесуальна форма проведення НСРД мають певні недоліки, а проведення НСРД супроводжується порушенням прав людини.

Однією з проблем чинного КПК в окресленій сфері є прогалина щодо визначення конкретного суб'єкта проведення НСРД за дорученням слідчого чи прокурора та суб'єкта, що може бути залученим до проведення НСРД. Це також одне з найбільш спірних і обговорюваних питань у науці кримінального процесуального права, тому що воно стосується: по-перше, результативності та ефективності проведення НСРД, по-друге, допустимості доказів, отриманих під час проведення останніх, по-третє, дотримання вимог чинного КПК України щодо недопустимості розголошення даних досудового розслідування.

Так, відповідно до ч. 6 ст. 246 КПК України, НСРД має право проводити слідчий, який здійснює досудове розслідування злочину або за його дорученням - уповноважені оперативні підрозділи Національної поліції, органів безпеки, Національного антикорупційного бюро України, Державного бюро розслідувань, органів, що здійснюють контроль за додержанням податкового і митного законодавства, органів Державної кримінально-виконавчої служби України, органів Державної прикордонної служби України [2]. На нашу думку, ця норма викладена нечітко та йде в розріз з іншими нормами КПК України, які стосуються процедури отримання дозволу на проведення НСРД. Таке формулювання означає, що будь-хто із співробітників визначених оперативних підрозділів може за дорученням провести НСРД.

Викладаючи ч. 6 ст. 246 КПК України, законодавець не врахував того, що йдеться не про просту слідчу дію (скажімо, допит, який може провести будь-хто зі співробітників оперативних підрозділів за дорученням слідчого в порядку п. 3 ч. 2 ст. 40 КПК України), а про НСРД, дозвіл на проведення якої має винятковий характер, отримується у визначеному законодавством порядку з урахуванням специфіки проведення. Ураховуючи складність проведення НСРД, а також можливість суттєвого обмеження конституційних прав людини під час їх проведення, слід більш конкретизовано визначити суб'єкта проведення у законодавстві.

Стосовно означеної проблеми слід звернути увагу на п. 3 ч. 4 ст. 248 КПК України, відповідно до якого ухвала слідчого судді про дозвіл на проведення негласної слідчої (розшукової) дії має відповідати загальним вимогам досудових рішень, передбачених КПК України, а також містити передбачені в 
ній відомості. Цікаво, що серед цих відомостей інформація про особу (осіб), які б мали право проводити негласну слідчу (розшукову) дію, відсутня. Ч. 6 ст. 246 КПК України викладена так, що в ній ідеться про широке коло виконавців, а не про конкретну особу. Водночас Інструкція про організацію проведення НСРД у Розділі III лише в загальних рисах урегульовує питання залучення співробітників (працівників) уповноваженого оперативного підрозділу до проведення НСРД. Так, відповідно до п. 3.3 Інструкції, слідчий, прокурор надсилає доручення керівникові органу, під юрисдикцією якого знаходиться місце вчинення кримінального правопорушення і в складі якого знаходяться орган розслідування та / або оперативні підрозділи, уповноважені на проведення негласних слідчих (розшукових) дій (ст. 246 КПК України).

Залежно від злочину, який розслідується, та статусу особи, щодо якої проводиться негласна слідча (розшукова) дія, інших чинників слідчий, за погодженням із керівником органу досудового розслідування відповідного рівня, може доручати проведення негласної слідчої (розшукової) дії керівникові іншого правоохоронного органу, зокрема того, під юрисдикцією якого не знаходиться місце вчинення кримінального правопорушення, з обгрунтуванням такої необхідності (підпункт 3.3.1). Коли матеріали оперативно-розшукової діяльності були використані як приводи та підстави для початку досудового розслідування, доручення на проведення НСРД, як правило, надається оперативному підрозділу, який виявив злочин, але враховуються його повноваження (підпункт 3.3.2). Відповідно до підпункту 3.4.3, керівник органу відповідно до відомчих нормативно-правових актів визначає виконавця - оперативний підрозділ (оперативні підрозділи), а не конкретного виконавця.

Згідно з пунктом 3.8. уповноважений оперативний підрозділ для виконання доручення слідчого, прокурора з урахуванням необхідності забезпечення умов для проведення НСРД залучає на підставі свого завдання відповідні оперативні та оперативно-технічні підрозділи [3].

Водночас слід звернути увагу на той факт, що в Розділі I «Загальні положення» Інструкції дається лише визначення уповноваженої особи на проведення НСРД, якою є співробітник (працівник) уповноваженого оперативного підрозділу, залучений за рішенням керівника до проведення або участі у проведенні негласної слідчої (розшукової) дії, інші особи, залучені за рішенням слідчого, прокурора, оперативного підрозділу (п.1.7.2.). На практиці це призводить до того, що слідчі, прокурори надають доручення керівникові органу оперативного підрозділу, останній працівникам оперативного підрозділу, а вони можуть передати виконання цього доручення іншим оперативно-технічним підрозділам. Виникає ситуація, за якої проводить НСРД один співробітник правоохоронного органу, а протокол про іiі проведення складає інший. I до того ж проведення НСРД особою, щодо якої відсутні дані про те, що саме їй доручено проведення НСРД, призводить до недопустимості зібраних доказів, оскільки одним із критерії їх допустимості $€$ збирання уповноваженим суб'єктом.

Таким чином, пропонуємо ч. 2 ст. 248 КПК України, яка містить вимоги до клопотання про дозвіл на проведення НСРД пунктом 10 у такій редакції 
(...у клопотанні зазначається): «відомості про особу (осіб) виконавия (прізвище, ім'я, по батькові, посада, оперативний підрозділ органу за відповідною територіальною юрисдикцією), а також відомості про осіб, які будуть залучатися до проведення даної НСРД».

Продовжуючи дослідження цієї проблеми, також слід звернути увагу на положення п.1 ч. 2 ст. 39 КПК України (повноваження керівника органу досудового розслідування), Так, згідно з цією нормою, керівник органу досудового розслідування уповноважений визначати слідчого (слідчих), який здійснюватиме досудове розслідування, а у випадках здійснення досудового розслідування слідчою групою - визначати старшого слідчої групи, який керуватиме діями інших слідчих.

Як уже зазначалося, розглядаючи клопотання про надання дозволу на проведення НСРД, слідчий суддя не має даних про прізвище, ім'я та по батькові осіб, що будуть проводити НСРД або долучатися до них, а також ïx посади та звання. I як підтверджує слідчо-прокурорська практика, а також практика адвокатської діяльності, дійсна законодавча прогалина загрожує допустимості доказів із причин, що вже названо.

Із метою зниження ризиків порушення прав людини та забезпечення допустимості доказів, пропонуємо внести зміни до низки статей КПК України, які спрямовані на попереднє узгодження керівниками органів досудового розслідування та оперативних підрозділів кандидатури конкретного виконавця доручення слідчого чи прокурора на проведення НСРД, зокрема: 1) п.3. ч.2 ст.40 КПК України, викласти так: «доручати проведення слідчих (розшукових) дій, а також негласних слідчих (розшукових) дій відповідним оперативним підрозділам, у порядку, визначеному cm. 246 щъього Кодексу»; 2) ч. 6 ст. 246 КПК України, доповнити таким реченням: «Оперативний працівник уповноваженого оперативного підрозділу, який буде виконувати доручення слідчого про проведення НСРД, визначається керівниками органу досудового розслідування та оперативного підрозділу до звернення слідчого, прокурора з клопотанням до слідчого судді про надання дозволу на проведення НСРД або до прийняття слідчим чи прокурором рішення про проведення НСРД у випадках, передбачених изим Кодексом»; 3) ч. 4 ст. 248 КПК України доповнити пунктом 6 , розширивши перелік відомостей, які має містити ухвала слідчого судді про надання дозволу на проведення НСРД, виклавши його так: «дані про особу (осіб), які будуть здійснювати НСРД (прізвище, ім'я, по батькові, посаду, звання), дані про особу (осіб), які будуть залучатися до проведення НСРД (прізвище, ім'я, по батькові, адреса проживання), а також оперативний підрозділ конкретного органу за відповідною територіальною юрисдикцією».

Стосовно недоліків під час застосування норм кримінального процесуального законодавства щодо проведення НСРД, то однією із суттєвих проблем є неприєднання до матеріалів кримінального провадження ухвали слідчого судді про надання дозволу на проведення НСРД, а інколи і клопотання слідчого/прокурора про проведення НСРД. Ураховуючи положення КПК 
України про те, що відомості про факт та методи проведення НСРД не підлягають розголошенню, а також Наказу СБУ «Про затвердження Зводу відомостей, що становлять державну таємницю», відповідно до якого відомості про факт або методи проведення НСРД, а також відомості, що дають змогу ідентифікувати особу, місце або річ, щодо якої проводиться чи планується проведення НСРД, розголошення яких створює загрозу національним інтересам і безпеці, становлять державну таємницю, такі документи, як постанова слідчого, прокурора про проведення НСРД, клопотання про дозвіл на їі проведення, ухвала слідчого судді про дозвіл на проведення НСРД та додатки до нього, протокол про проведення НСРД, які містять вищезазначені відомості, підлягають відповідно до Інструкції про організацію проведення НСРД засекречуванню.

Як бачимо із вищезазначеного, законодавець до державної таємниці відносить як відомості, що отриманні в результаті НСРД, так і процесуальні документи, що є законною підставою для їх проведення. Засекречування таких матеріальних носіїв інформації здійснюється слідчим, прокурором, співробітником уповноваженого оперативного підрозділу, слідчим суддею шляхом надання на підставі Зводу відомостей, що становлять державну таємницю (Розгорнутих переліків відомостей, що становлять державну таємницю), відповідному документу грифа секретності.

Після завершення проведення НСРД грифи секретності матеріальних носіїв інформації щодо їх проведення підлягають розсекреченню на підставі рішення прокурора i, з урахуванням обставин кримінального провадження та необхідності використання матеріалів НСРД як доказів після проведення таких дій, якщо витік зазначених відомостей не завдасть шкоди національній безпеці України [3].

Як показує судова та адвокатська практика в матеріалах кримінального провадження зазвичай відсутня ухвала слідчого судді про надання дозволу на проведення НСРД, хоча очевидно, що саме цей документ є найважливішим серед усіх інших у сфері їх проведення, оскільки є правовою підставою здійснення негласних слідчих (розшукових) дій.

Варто зауважити, що значення та роль будь-якого судового рішення в кримінальному процесі складно переоцінити. Виходячи з теорії процесуального документування, такі документи, оформлені у відповідності до вимог закону, складають «матеріальну», «речову» частину процесуальної форми, утворюють найбільш «видимий» іï бік. Саме в процесуальних документах (рішеннях та протоколах) знаходяться відповіді на певні правові питання [4, с. 10-11]. Відомості, що містяться в документі (рішенні), матимуть юридичну силу лише тоді, якщо вони не тільки отримані в установленому законі порядку, а й належним чином оформлені. Лише «правильно оформлені процесуальні документи і процесуальна форма в цілому забезпечують встановлення істини у справі і сприяють забезпеченню прав людини» [4, с. 11].

Вагомість ухвали про проведення НСРД актуалізується ще й тим, що, по-перше, у більшості випадків йдеться про таємне обмеження не будьяких, зокрема конституційних прав та свобод людини, по-друге, рішення слідчого судді є остаточним і не підлягає оскарженню [5]. 
Коваль $A$. А. Теоретичні та практичні проблеми правового регулювання негласних... 59

3 урахуванням викладеного слід акцентувати увагу на тому, що ухвала слідчого судді про надання дозволу на проведення НСРД у контексті окреслених тут проблем є матеріальним об’єктом, у якому слідчим суддею з дотриманням встановленої законом процесуальної форми, зафіксовані фактичні дані, зміст і результат прийнятого рішення (або вчиненої дії), що має правове значення для конкретного кримінального провадження.

За відсутності такого процесуального документа адвокат підзахисного, відносно якого проводили НСРД, може клопотати про визнання результатів, отриманих під час проведення НСРД, недопустимими, мотивуючи своє рішення положеннями ч. 1 ст. 87 КПК України: «недопустимими є докази, отримані внаслідок істотного порушення прав та свобод людини, гарантованих Конституцією та законами України, міжнародними договорами, згода на обов'язковість яких надана Верховною Радою України, а також будь-які інші докази, здобуті завдяки інформації, отриманій унаслідок істотного порушення прав та свобод людини». При цьому відповідно до ч. 2 цієї статті суд зобов'язаний визнати істотними порушеннями прав людини й основоположних свобод, зокрема здійснення процесуальних дій, які потребують попереднього дозволу суду, без такого дозволу або з порушенням його суттєвих умов.

Питання законності, обгрунтованості і доцільності рішень, що стали підставою проведення НСРД як однієї із гарантій забезпечення прав людини у кримінальному судочинстві, є предметом розгляду ЄСПЛ. Так, ЄСПЛ у рішенні у справі «Волохи проти України» від 2 листопада 2006 року визначає, що «суд має бути впевненим щодо існування адекватного та ефективного захисту від зловживання, оскільки система заходів таємного спостереження, що розроблена для захисту національної безпеки та громадського порядку, пов'язана 3 ризиком порушення або навіть зруйнування принципів демократії на підставі iї захисту. Такі гарантії захисту мають бути чітко встановлені законом та мають застосовуватись до нагляду за діяльністю відповідних органів або служб. У наглядових провадженнях мають дотримуватись цінності демократичного суспільства настільки добросовісно, наскільки це можливо, зокрема верховенство права. Верховенство права, між іншим (inter alia) передбачає, що втручання органів виконавчої влади у права осіб має підлягати ефективному контролю, який зазвичай має здійснюватись судовим органом, щонайменше як останньою інстанцією, оскільки судовий контроль надає найбільші гарантії незалежності, безсторонності та здійснення належного провадження» [6].

При цьому ЄСПЛ висловлює позицію, щодо якої повноваження державних органів на проведення таємного спостереження за громадянами в під час кримінального розслідування визнаються Конвенцією в тій мірі, в якій вони є абсолютно необхідними [7].

Однак на практиці досить часто правообмеження, пов'язані із застосуванням НСРД, є не досить обгрунтованими. Як зазначається в матеріалах узагальнення судової практики розгляду клопотань про дозвіл на проведення НСРД слідчим суддею «найчастіше висновки слідчих про те, що особа причетна до вчинення злочину, контактує з підозрюваним, або $з$ інших підстав володіє інформацією про злочин, є лише припущеннями, які 
не обгрунтовуються жодними доказами, які б підтверджували ці висновки. Трапляються також випадки, коли слідчі посилаються на докази, що, на їхню думку, свідчать про причетність особи до вчинення злочину, однак за своїм змістом зазначені докази таких обставин не підтверджують або такі докази взагалі відсутні в матеріалах кримінального провадження [8].

Найчастіше слідчий під час вирішення питання про проведення НСРД керується лише припущеннями. Хоча очевидно, що в правовій державі обмеження та порушення прав людини не можуть носити еспериментальний характер та проводитися без достатніх на те підстав. На жаль, досить часто виникають випадки, коли слідчий суддя надає дозвіл на проведення НСРД, не дивлячись на відсутність у клопотанні зазначених у ч. 2 ст. 248 КПК України вимог. Це похитує гарантії прав і законних інтересів людини у кримінальному судочинстві. Таким чином, відсутність у матеріалах кримінального провадження клопотання слідчого/прокурора про дозвіл на проведення НСРД або ухвали слідчого судді про надання такого дозволу має бути підставою для визнання доказу, отриманого в результаті НСРД, недопустимим.

Висновки. Отже, введення до КПК інституту НСРД є, з одного боку, дієвим інструментом у розкритті злочинів, а 3 іншого - загрозою невиправданого порушення конституційних прав людини. Тому суд і правоохоронні органи мають чітко й неухильно слідувати приписам закону. На жаль, проведені дослідження свідчать про недосконалість кримінального процесуального законодавства у цій сфері, що повністю суперечить духу верховенства права, закріпленого у Конституції України і міжнародних угодах, ратифікованих нашою державою. У зв'язку з цим першочерговим завданням науковців $€$ вивчення дійсних проблем та вироблення пропозицій щодо їх вирішення, а беззаперечним обов'язком законодавців - негайне втілення цих пропозицій у норми закону.

\section{Література}

1. Тагієв С.Р. Деякі проблемні питання проведення негласних слідчих (розшукових) дій. Вісник Верховного Суду України. 2014. № 10. С. 40-47.

2. Кримінальний процесуальний кодекс України від 13.04.2012 № 4651-VI. База даних Законодавство України / ВР України. URL: http://zakon2.rada.gov.ua/laws/show/465117 (дата звернення: 21.11.2018).

3. Про затвердження Інструкції про організацію проведення негласних слідчих (розшукових) дій та використання їх результатів у кримінальному провадженні. Наказ Генеральної прокуратури України, МВС України, Служби безпеки України, Адміністрації державної прикордонної служби України, Міністерства фінансів України, Міністерства юстиції України від 16.11.2012 № 114/1042/516/1199/936/1687/5. URL: http:/ / zakon4.rada.gov.ua/laws / show/v0114900-12/page. (дата звернення: 21.11.2018).

4. Михайленко А.Р. Складання процесуальних актів по кримінальним справам. Київ: Вища школа, 1989. 199 с.

5. Кудінов С.С., Шехавцов Р.М., Дроздов О.М., Гриценко С.О. Негласні слідчі (розшукові) діï та використання результатів оперативно-розшукової діяльності у кримінальному провадженні : навч.-практ. посіб. Харків: Оберіг, 2013. 344 с.

6. Рішення Європейського Суду з прав людини у справі «Волохи проти України» від 2 листопада 2006 року База даних Законодавство України / BP України. URL: http:/ zakon.rada.gov.ua / laws / show $/ 974 \_138$ ?find $=1 \&$ text $=\%$ E2 \% EF\% E5\%E2\%ED\%E5 (дата звернення: 21.11.2018) 
7. Case of Klass and others v. Germany (Application no. 5029/71) : Judgment European Court of Human Rights, Strasbourg, 6 September 1978. HUDOC: database. URL: http:// hudoc.echr.coe.int/eng?i=001-57510 (date of request:30.08.2017).

8. Чернушенко А.В., Приндюк М.В. Узагальнення судової практики розгляду клопотань про дозвіл на проведення негласних слідчих (розшукових) дій слідчим суддею. URL: http:/ / www.apcourtkiev.gov.ua/ apcourtkiev/uk/publish/article/98401 (дата звернення: 21.11.2018)

\section{А н о т а ц}

Коваль $A$. $A$. Теоретичні та практичні проблеми правового регулювання негласних слідчих (розшукових) дій. - Стаття.

У статті визначено окремі актуальні проблеми правового регулювання та провадження негласних слідчих (розшукових) дій в аспекті забезпечення конституційних прав людини. Серед проблем виділено такі, як прогалина чинного КПК України, що виражається у нечіткому (неконкретному) визначенні суб'єкта проведення НСРД; відсутність у матеріалах кримінального провадження ухвал слідчого судді про надання дозволу на проведення НСРД, і клопотання слідчого/прокурора про проведення НСРД та інші. Зроблено висновки та пропозиції до законодавства.

Ключові слова: негласні слідчі (розшукові) дії, права людини, процесуальна форма, оперативний підрозділ, слідчий, прокурор, слідчий суддя, ухвала, клопотання.

\section{Анн о т а ци я}

Коваль $A$. $A$. Теоретические и практические проблемы правового регулирования негласных следственных (розыскных) действий. - Статья.

В статье определены отдельные актуальные проблемы правового регулирования и осуществления негласных следственных (розыскных) действий в аспекте обеспечения конституционных прав человека. Среди проблем выделены следующие: пробелы действующего УПК Украины, которые состоят в нечетком (неконкретном) определении субъекта проведения НСРД; отсутствие в материалах уголовного производства постановлений следственного судьи о предоставлении разрешения на проведение НСРД, и ходатайства следователя / прокурора о проведении НСРД и другие. Сделаны выводы и предложения в законодательство.

Ключевые слова: негласные следственные (розыскные) действия, права человека, процессуальная форма, оперативное подразделение, следователь, прокурор, следственный судья, постановление, ходатайство.

\section{S u m m a r y}

Koval $A$. A. The theoretical and practical problems of legal regulation of the secret investigative (search actions). - Article

In the article the certain topical issues of legal regulation and the implementation of the secret investigative (search) actions in the aspect of the ensuring of the constitutional human rights are determined. Among the issues were selected: the gaps of the current CPC of Ukraine, which is expressed in the fuzzy (non-specific) definition of the subject of the SISA; the absence in the criminal proceedings of the decisions of the investigating judge on the authorization of the SISA, and sometimes the petition of the investigator / prosecutor regarding the conducting of the SISA, and others. Conclusions and suggestions to legislation are made.

Key words: secret investigative (search) actions, human rights, investigator, prosecutor, investigating judge, petition of the investigator, procedural form, order. 